\title{
ע Terveyttä edistävään ruokavalioon yhteydessä olevat tekijät korkeakouluopiskelijoilla
}

Korkeakouluopiskelijoiden terveystutkimuksessa on selvitetty alle 35-vuotiaiden perustutkintoa suorittavien suomalaisten korkeakouluopiskelijoiden terveys- ja ruokailutottumuksia joka neljäs vuosi vuodesta 2000 alkaen. Vuoden 2012 tutkimuksessa selvitettiin ensimmäistä kertaa ruokavalion laatua kokonaisuutena. Tämän artikkelin tavoitteena on kuvata yliopisto- ja ammattikorkeakouluopiskelijoiden ruokavalion laatua ja ravitsemussuositusten mukaisen, terveyttä edistävän ruokavalion toteutumista painoindeksin, terveystietoisuuden, koetun terveyden, toimeentulon ja pääaterian syöntipaikan mukaan sukupuolittain.

Korkeakouluopiskelijoiden terveystutkimus toteutettiin vuonna 2012 lomakekyselynä postitse, mutta vastaaminen oli mahdollista myös internetissä. Opiskelijoiden ruokavalion laatua selvitettiïn ravitsemussuositusten mukaisen, terveyttä edistävän ruokavalion toteutumista kuvaavalla ravintomittarilla (Index of Diet Quality, IDQ). Kyselyyn vastasi yhteensä 4403 (44\%) opiskelijaa.

Ravitsemussuositusten mukainen, terveyttä edistävä ruokavalio toteutui naisilla useammin kuin miehillä ja yliopisto-opiskelijoilla useammin kuin ammattikorkeakouluopiskelijoilla. Ylipainoisilla ja lihavilla oli suurempi riski epäterveelliseen ruokavalioon normaalipainoisiin verrattuna. Terveyttä edistävän ruokavalion toteutuminen ja siten parempi ruokavalion laatu liittyivät yliopistossa opiskeluun, opiskelijoiden normaalipainoisuuteen, terveystietoisuuteen ruokailun suhteen, hyvään koettuun terveyteen, hyvään toimeentuloon sekä pääaterian syömiseen opiskelija- tai työpaikkaravintolassa.

Terveystietoisuus ruokavalion suhteen, sukupuoli ja korkeakoulusektori ovat yhteydessä terveyttä edistävän ruokavalion toteutumiseen. Ruuan terveellisyyden ajattelu sen hankintatilanteessa oli merkittävin opiskelijoiden ruokavalion laatuun yhteydessä oleva tekijä. Lisäksi ali- ja ylipainoisuus oli yhteydessä heikompaan ruokavalion laatuun. Pääaterian nauttiminen opiskelija- tai työpaikkaravintolassa paransi opiskelijoiden ruokavalion laatua, joten opiskelijoiden ruokailua opiskelijaruokaloissa tulisi edistää ja tukea.

\section{Asiasanat: Opiskelijat Terveys Ruokavalion laatu Ruokatottumukset \\ HANNA LAGSTRÖM, SANNA LUOTO, JOHANNA MÄKELÄ, JENNI IIROLA, KRISTINA KUNTTU}

\section{JOHDANTO}

Elintavoilla ja ravinnolla on tärkeä merkitys terveyden edistämisessä ja kroonisten tautien ehkäisyssä (1). Hyvä ravinto ylläpitää terveyttä, hyvinvointia ja toimintakykyä. Suomalaiset ravitsemussuositukset ovat terveyttä edistävän ruokavalion perusta (2).
On havaittu, että ylimpään koulutusryhmään kuuluvilla ravitsemussuositusten mukaiset ruokatottumukset toteutuvat useammin kuin alemmilla koulutusryhmillä (3). Koulutus on yhteydessä myös ruokapalveluiden käyttöön sekä koettuun terveyteen. Korkeasti koulutetut 
nauttivat lounaan useammin henkilöstöravintoloissa kuin muut, ja ruokapalveluiden käyttö on yhteydessä yleisesti terveellisempiin ruokailutottumuksiin $(4,5)$. Joukkoruokailun piirissä syövien lasten $(7,8)$ ja myös aikuisten $(4,6,9,10)$ ruokatottumukset ovat tutkimusten mukaan lähempänä ravitsemussuosituksia muualla lounastaviin verrattuna. Elintarvikkeisiin kuluttaminen on yleisesti yhteydessä kotitalouden tulotasoon, ja taloudellisten vaikeuksien on todettu olevan yhteydessä vähemmän terveellisiin ruokatottumuksiin $(11,12)$.

Korkeakouluopiskelijoiden opiskelijaruokailua tuetaan valtion varoin ateriatuen muodossa (13) ja sen edellytykset on kirjattu asetukseen korkeakouluopiskelijoiden ruokailun tukemisen perusteista (54/2012). Suomalaisista 15-64-vuotiaista noin joka kolmas ruokaili päivittäin henkilöstö- tai opiskelijaravintolassa vuosina 20082010 (14), kun taas koko väestöstä useammin henkilöstö- ja opiskelijaravintoloissa ruokailivat nuorimmat eli 15-24-vuotiaat, joista $72 \%$ oli tuetun ruokailun piiriin kuuluvia koululaisia tai opiskelijoita. Vuoden 2012 korkeakouluopiskelijoiden terveystutkimuksen mukaan opiskelijoista noin puolet söi päivittäisen pääaterian opiskelijatai työpaikkaravintolassa (15). Kanadalaisen tutkimuksen mukaan suhtautuminen terveelliseen ruokavalioon oli korkeakouluopiskelijoilla selkeästi yhteydessä sekä sen hetkiseen ravitsemustilaan että terveellisen ruokavalion toteutumisen todennäköisyyteen (16). Mitä tärkeämmäksi terveellinen syöminen koettiin, sitä parempi oli sen hetkinen ravitsemustila ja sitä todennäköisemmin terveellinen ruokavalio myös toteutui. Suomalaisessa STRIP -tutkimuksessa on havaittu, että lukiolaisten ruokavalinnat olivat lähempänä ravitsemussuosituksia (aamupalojen nauttimisen säännöllisyys sekä kasvisten, hedelmien ja marjojen runsaampi käyttö) kuin ammatillisessa oppilaitoksissa opiskelevien nuorten (17). Tuoreessa italialaisessa tutkimuksessa havaittiin miessukupuolen selittävän heikompaa terveyskäyttäytymistä ja osaltaan vähäistä kasvisten käyttöä (18). Toisaalta, on myös esitetty tuloksia parisuhteen myönteisistä vaikutuksista kumppanin terveyskäyttäytymiseen (19). Nuorten aikuisten ruokakäyttäytymistä on tutkittu aiemmin lähinnä yksittäisten tekijöiden avulla tai niiden kautta. Monet aikuisiän terveyteen vaikuttavat elintavat ja elinolot vakiintuvat jo nuorena tai nuorena aikuisena, ja näillä terveystottumuksilla voi olla hyvinkin kauaskantoisia seurauksia.

Tässä tutkimuksessa haluttiin selvittää suomalaisten korkeakouluopiskelijoiden ruokavalion laatua kokonaisvaltaisesti. Tavoitteena oli tutkia sekä korkeakouluopiskelijoiden terveyttä edistävän ruokavalion toteutumista että epäterveellisen ruokavalion riskiä. Tutkimuksessa havainnoitiin painoindeksiä, ruokailun terveystietoisuutta, koettua terveyttä ja pääaterian syöntipaikkaa. Myös vastaajien sosioekonominen tausta sekä parisuhde- ja perhetilanne otettiin huomioon.

\section{AINEISTO JA MENETELMÄT}

Tutkimuksessa käytettiin helmi-kesäkuussa 2012 toteutetun Korkeakouluopiskelijoiden terveystutkimuksen aineistoa, jossa kohdejoukkona olivat alle 35-vuotiaat perustutkintoa suorittavat suomalaiset korkeakouluopiskelijat (15). Yliopistoopiskelijoiden otanta tehtiin Ylioppilaiden terveydenhoitosäätiön (YHTS) asiakasrekisteristä ja ammattikorkeakouluissa opiskelevien otos vastaavasti oppilaitosten opiskelijarekistereistä. Otoksen koko oli 9992 opiskelijaa, joista 47 \% oli miehiä. Puolet otoksesta opiskeli yliopistoissa ja puolet ammattikorkeakouluissa. Tutkimus suoritettiin lomakekyselynä postitse, mutta vastaaminen oli mahdollista myös internetissä. Sähköisiä vastaamiskehotuksia lähetettiin neljä ja yksi uusintakysely postitse.

Kyselylomakkeeseen vastasi yhteensä 4403 (44\%) opiskelijaa, joista miehiä oli 1628 (37\%). Yliopisto-opiskelijat vastasivat ammattikorkeakouluopiskelijoita aktiivisemmin ( $49 \%$ vs. $40 \%$ ) (Taulukko 1). Vastanneista ammattikorkeakouluopiskelijoista $66 \%$ ja yliopisto-opiskelijoista $52 \%$ oli alle 24-vuotiaita. Vastanneiden tarkempi ikäjakauma on esitetty taulukossa 1 .

\section{RUOKAVALION LAATU}

Opiskelijoiden ruokavalion laatua selvitettiin validoidulla Index of Diet Quality (IDQ) -mittaristolla $(20,21)$. Mittari kuvaa terveyttä edistävän ruokavalion toteutumista suhteessa ravitsemussuosituksiin yhteensä 18 kysymyksen avulla (liite 1). Kysymykset käsittelevät täysjyväviljan, rasvan, kalan, kasvisten, marjojen ja hedelmien, sokerin ja maitotuotteiden kulutusta sekä säännöllistä ateriarytmiä. Vastausten perusteella ruokavalio pisteytetään nollasta viiteentoista, ja saatujen pisteiden avulla tulkitaan terveyttä edistävän 
Taulukko 1. Vastausaktiivisuus sukupuolen ja korkeakoulusektorin mukaan koko korkeakouluopiskelijoiden terveystutkimus 2012 -aineiston osalta (15). Ositettu satunnaisotanta alle 35-vuotiaista perustutkintoa suorittavista suomalaisista korkeakouluopiskelijoista.

\begin{tabular}{|c|c|c|c|c|c|c|}
\hline & \multicolumn{3}{|c|}{ Ammattikorkeakoulu (AMK) } & \multicolumn{3}{|c|}{ Yliopisto $(\mathrm{YO})$} \\
\hline & $\begin{array}{l}\text { Otos } \\
(\mathrm{N})\end{array}$ & $\begin{array}{c}\text { Vastanneet } \\
\text { (n) }\end{array}$ & Vastaus- $\%$ & $\begin{array}{r}\text { Otos } \\
(\mathrm{N})\end{array}$ & $\begin{array}{l}\text { Vastanneet } \\
\text { (n) }\end{array}$ & Vastaus- $\%$ \\
\hline Miehet & 2315 & 711 & 30,7 & 2344 & 917 & 34,9 \\
\hline Alle 22 -vuotiaat & 497 & 152 & 21,4 & 421 & 161 & 17,6 \\
\hline 22-24-vuotiaat & 953 & 269 & 37,8 & 678 & 269 & 29,3 \\
\hline 25-29-vuotiaat & 670 & 222 & 31,2 & 875 & 354 & 38,6 \\
\hline 30-35-vuotiaat & 195 & 68 & 9,6 & 370 & 133 & 14,5 \\
\hline Naiset & 2655 & 1267 & 47,3 & 2652 & 1508 & 52,1 \\
\hline Alle 22 -vuotiaat & 819 & 394 & 31,1 & 563 & 315 & 20,9 \\
\hline 22-24-vuotiaat & 1009 & 488 & 38,5 & 824 & 519 & 34,4 \\
\hline 25-29-vuotiaat & 578 & 284 & 22,4 & 895 & 493 & 32,7 \\
\hline 30-35-vuotiaat & 249 & 10 & 8,0 & 370 & 181 & 12,0 \\
\hline Kaikki & 4970 & 1978 & 39,6 & 4996 & 2425 & 48,5 \\
\hline
\end{tabular}

ruokavalion toteutuminen (liite 2). Terveyttä edistävän ruokavalion katsotaan toteutuvan, kun pisteitä saa kymmenen tai enemmän. Ruokavalion laatupisteitä voidaan tarkastella myös jatkuvana muuttujana ilman jakoa terveyttä edistävään tai epäterveelliseen ruokavalioon. Molempia lähestymistapoja hyödynnettiin. Validointitutkimuksessa mittarin havaittiin kuvaavan luotettavasti muun muassa proteiinin, sakkaroosin, kuidun, kalsiumin ja C-vitamiinin saantia sekä ruokavalion rasvojen laatua verrattuna 7 päivän ruokapäiväkirjoihin (18). Ruokavalion laatua kuvaavana käsitteenä käytetään "terveyttä edistävä ruokavalio" ( $\geq 10$ IDQ-pistettä) ja vastaavasti käsitettä "epäterveellinen ruokavalio", jos IDQ-pisteitä on alle 10.

\section{TAUSTATIEDOT}

Korkeakouluopiskelijoiden terveystutkimuksen (15) lomakkeen kysymyksistä käytettiin tutkittavien pituutta ja painoa, joiden perusteella jokaiselle laskettiin painoindeksi $\left(\mathrm{kg} / \mathrm{m}^{2}\right)$. Painoindeksiä (BMI) käytettiin neliluokkaisena (alipainoiset BMI <18,5, normaalipainoiset BMI 18,5-24,9, ylipainoiset BMI 25,0-29,9 ja lihavat BMI $\geq 30,0$ ). Ruokavalion perusteella terveystietoisuutta mitattiin kysymyksellä, kuinka usein opiskelija ajattelee ruoan terveellisyyttä sitä hankkiessaan. Tämä muuttuja luokiteltiin kahteen luokkaan: 1) ajattelee ruuan terveellisyyttä usein tai 2) ajattelee ruuan terveellisyyttä silloin tällöin tai harvemmin.
Opiskelijoilta kysyttiin myös, millaiseksi he kokevat oman terveytensä (1=hyvä; $2=$ =melko hyvä; $3=$ keskitasoinen tai huonompi) ja missä he syövät yleensä päivän pääaterian (1=opiskelija- tai työpaikkaravintola; $2=$ muu eli omalla asunnolla, vanhempien luona tai muualla). Toimeentuloa mitattiin kysymyksellä rahojen riittävyydestä viimeisen vuoden aikana. Vastaajat luokiteltiin kolmeen luokkaan seuraavasti: 1) toimeentulo erittäin hyvä tai hyvä; 2) toimeentulo vaatii säästämistä ja 3) toimeentulo niukka ja epävarma. Taustatietona käytettiin myös ikää, sukupuolta ja opiskelupaikkaa (yliopisto tai ammattikorkeakoulu), parisuhdetta (kyllä/ei) ja mahdollisia lapsia (yksi tai useampi/ei lapsia) sekä kolmiluokkaisena vanhempien (isä tai äiti) ammattiasemaa vastaajan ollessa 15-vuotias: alin ryhmä (omaa kotitaloutta hoitavat, opiskelijat, työttömät ja eläkeläiset), keskiryhmä (maanviljelijät, pienyrittäjät tai itsenäisen ammatinharjoittajat ja työntekijät) ja ylin ryhmä (yrittäjät, ylemmät toimihenkilöt, alemmat toimihenkilöt).

\section{TILASTOMENETELMÄT}

Tulokset on esitetty jatkuvien muuttujien osalta keskiarvoina ja -hajontoina, kategoriset muuttujat frekvensseinä ja prosentteina. Vasteen ja selittävien muuttujien välisiä suhteita tutkittiin myös ristiintaulukointien avulla. Ruokavalion laatupisteiden keskiarvojen eroja testattiin painoindeksin, terveystietoisuuden, koetun terveyden, toimeen- 
Taulukko 2. Korkeakouluopiskelijoiden terveystutkimukseen vastanneiden taustamuuttujien tunnusluvut [keskiarvo (sd) tai prosenttiosuuksina (n)] sukupuolittain erikseen ammattikorkeakouluissa ja yliopistossa opiskeleville.

\begin{tabular}{|c|c|c|c|c|}
\hline \multirow[b]{2}{*}{ Muuttuja } & \multicolumn{2}{|c|}{ Miehet $(n=1628)$} & \multicolumn{2}{|c|}{ Naiset $(n=2775)$} \\
\hline & $\begin{array}{c}\text { AMK } \\
(\mathrm{n}=711)\end{array}$ & $\begin{array}{c}\mathrm{YO} \\
(\mathrm{n}=917)\end{array}$ & $\begin{array}{c}\text { AMK } \\
(\mathrm{n}=1267)\end{array}$ & $\begin{array}{c}\text { YO } \\
(\mathrm{n}=1508)\end{array}$ \\
\hline Keski-ikä, v & $24,4(3,4)$ & $25,3(3,7)$ & $23,7(3,5)$ & $24,8(3,7)$ \\
\hline Opiskeluaika, v* & $2,7(1,6)$ & $4,2(2,8)$ & $2,6(1,6)$ & $3,8(2,5)$ \\
\hline Ansiotyö (\%) & $58,7(411)$ & $57,6(522)$ & $66,1(827)$ & $64,0(957)$ \\
\hline Vanhempien ammattiasema, ylin**(\%) & $49,5(332)$ & $59,4(521)$ & $40,9(504)$ & $52,9(757)$ \\
\hline Parisuhteessa $(\%)$ & $54,3(382)$ & $61,8(563)$ & $70,5(883)$ & $68,8(1025)$ \\
\hline Lapsia (\%) & $5,4(34)$ & $7,7(65)$ & $10,9(129)$ & $8,7(123)$ \\
\hline Ruokavalion laatupisteet ${ }^{* * *}$ & $8,4(2,5)$ & $8,9(2,4)$ & $8,9(2,4)$ & $9,5(2,3)$ \\
\hline Painoindeksi, $\mathrm{kg} / \mathrm{m}^{2}$ & $25,0(4,0)$ & $24,6(3,5)$ & $23,4(4,3)$ & $22,7(4,0)$ \\
\hline Ylipainoisia ja lihavia, $\mathrm{BMI} \geq 25 \mathrm{~kg} / \mathrm{m}^{2}$ & $41,9(297)$ & $38,9(354)$ & $27,6(346)$ & $18,5(276)$ \\
\hline
\end{tabular}

tulon sekä pääaterian syöntipaikan eri ryhmien välillä $\chi^{2}$-testillä.

Terveyttä edistävään ruokavalioon vaikuttavia tekijöitä tutkittiin myös usean muuttujan regressioanalyysin avulla, jossa vasteena olivat IDQ-pisteet jatkuvana muuttujana. Regressioanalyysia varten luotiin kategorisista taustamuuttujista indikaattorimuuttujia. Ensimmäisessä analyysissa olivat mukana kaikki indikaattorimuuttujat sekä jatkuva muuttuja, ikä. Toisessa analyysissa pidettiin ne ensimmäisen analyysin muuttujat, jotka olivat tilastollisesti merkitseviä sekä vakioivana tekijänä ikä. Tuloksissa on esitetty regressiokerroin $(\beta)$, keskivirhe $(\mathrm{SE})$, havaittu merkitsevyystaso ja mallin selitysaste $\left(\mathrm{R}^{2}\right)$.

Epäterveellisen ruokavalion toteutumista pyrittiin selittämään kategoristen taustamuuttujien sekä jatkuvan muuttujan, iän, avulla. Selittävien muuttujien yhteyksiä binääriseen vasteeseen tarkasteltiin logistisen regressioanalyysin ja sen avulla saatujen riskisuhteiden (OR) avulla. Jokaisen taustamuuttujan yhteyttä vasteeseen tutkittiin ensin erikseen omissa malleissaan ja sen jälkeen selittäjiä tarkasteltiin yksitellen mallissa, joka oli vakioitu sukupuolen, korkeakoulun ja iän suhteen.
Tilastollisen merkitsevyyden rajana on kaikissa analyyseissa $\mathrm{p}<0,05$. Analyyseissa käytettiin 95\% luottamusväliä (LV). Analyysit on tehty IBM SPSS Statistics -ohjelmiston versioilla 21 ja 22 sekä SAS-ohjelmiston versiolla 9.4 (SAS Institute, Cary, NC, USA).

\section{TULOKSET}

Ammattikorkeakoulujen opiskelijat olivat noin vuoden nuorempia kuin yliopisto-opiskelijat: keski-ikä oli miehillä 24,4 vuotta (AMK) ja 25,3 vuotta (YO); naisilla vastaavat luvut olivat 23,7 vuotta ja 24,8 vuotta (Taulukko 2). Ammattikorkeakoulussa opiskelevilla oli vastaustaushetkellä takanaan opintoja keskimäärin vajaat kolme vuotta ja yliopisto-opiskelijoilla noin neljä vuotta. Noin $60 \%$ opiskelijoista kävi opiskelujen ohella ansiotyössä. Yliopisto-opiskelijoiden vanhemmista suurempi osa ammattikorkeakoulussa opiskeleviin verrattuna kuului ylimpään ammattiryhmään. Opiskelijoista parisuhteessa olevien määrä vaihteli $54 \%$ :sta (ammattikorkeakoulussa opiskelevat miehet) $70 \%$ :iin (ammattikorkeakoulussa opiskelevat naiset). Miesopiskelijoista 5-7\% ja naisopiskelijoilla noin joka kymmenennellä oli lapsia. Painoindeksin keskiarvo vaihteli välillä $22,7-25,0 \mathrm{~kg} / \mathrm{m}^{2}$ siten, että se oli matalin 
yliopistojen naisopiskelijoilla ja korkein ammattikorkeakoulujen miehillä. Ylipainoisia (BMI $\geq 25$ $\mathrm{kg} / \mathrm{m}^{2}$ ) oli ammattikorkeakoulussa opiskelevissa enemmän kuin yliopistoissa opiskelevien keskuudessa (AMK-miehet $42 \%$,YO-miehet $39 \%$, AMK-naiset $28 \%$, YO-naiset $19 \%$ ).

Ruokavaliosta voidaan yleisesti todeta, että naiset söivät miehiä yleisemmin päivittäin käytettäväksi suositeltuja ruokia (Kuvio 1). Ammattikorkeakoulussa olevista miehistä kasviksia söi päivittäin $45 \%$, naisista $60 \%$. Vastaavasti yliopistossa opiskelevista miehistä $56 \%$ ja naisista $73 \%$ söi päivittäin tai lähes päivittäin kasviksia. Kalaa opiskelijat söivät keskimäärin 1,3 päivänä viikossa ja vajaa $13 \%$ opiskelijoista söi kalaa vähintään kolme kertaa viikossa. Öljypohjaisten salaatinkastikkeiden käyttö oli runsainta yliopistossa opiskelevien naisten keskuudessa (n. 39\%) verrattuna muihin ryhmiin (33-35\%). Leipärasvana vajaa joka kymmenes opiskelija käytti 60-80\% rasvaa sisältäviä kasvirasvalevitteitä. Voin käyttäjiä oli suunnilleen saman verran, kun taas voi-kasviöljyseosta käytti kaikissa ryhmissä noin $40 \%$ opiskelijoista. Naisopiskelijoista noin $53 \%$ ja miesopiskelijoista noin $41 \%$ käytti rasvattomia maitovalmisteita (Kuvio 1).

\section{TERVEYTTÄ EDISTÄVÄN RUOKAVALION TOTEUTUMINEN}

Terveyttä edistävä ruokavalio ei keskimäärin toteudu millään opiskelijaryhmällä, sillä IDQ-pisteiden keskiarvo jäi kaikilla alle kymmenen. Tosin yliopistojen naisopiskelijat ylsivät varsin lähelle tätä kriteeriä. Ammattikorkeakoulussa opiskelevien ruokavalion IDQ-pisteiden keskiarvo oli yliopistossa opiskelevia hivenen matalampi sekä miehillä $(8,5$ vs. 8,9$)$ että naisilla $(8,9$ vs. 9,5) (Taulukko 2).

Terveyttä edistävä ruokavalio toteutui IDQmittarin mukaan naisilla useammin kuin miehillä $(48,1 \%$ vs. $39,6 \%$; p<0,001) ja yliopisto-opiskelijoilla useammin kuin ammattikorkeakouluopiskelijoilla $(48,2 \%$ vs. $41,5 \%$; p<0,001). Miehillä korkeakoulusektorien väliset erot terveyttä edistävän ruokavalion toteutumisessa olivat hieman pienemmät kuin (AMK-miehet 35,8 \% ,YO-miehet 42,6\%; p=0,007\%; AMK-naiset 43,9\%, YO-naiset 51,6\%; $<<0,001)$.

Painoindeksi oli yhteydessä terveyttä edistävän ruokavalion toteutumiseen vain yliopisto-opiskelijoilla siten, että huonoiten terveyttä edistävä ruokavalio toteutui alipainoisilla ja li- havilla miehillä ja ylipainoisilla naisilla ( $\mathrm{p}$-arvo: miehet 0,004 , naiset 0,01 ) (Kuvio 2).

Terveyttä edistävä ruokavalio toteutui useammin terveytensä hyväksi kokevilla kuin muilla ryhmillä sekä miehillä että naisilla ja molemmilla korkeakoulusektoreilla $(\mathrm{p}<0,001$ kaikille ryhmille) (Kuvio 2). Terveyttä edistävää ruokavaliota kuvaavat korkeat IDQ-pisteet $(\geq 10)$ oli hyväksi terveytensä kokevista miesopiskelijoista ammattikorkeakouluissa 44,7\%:1la ja yliopistoissa 49,6\%:lla. Naisilla vastaavat osuudet olivat 50,1\% ja 58,9\%. Keskitasoiseksi tai sitä huonommaksi terveytensä kokevista terveyttä edistävä ruokavalio toteutui noin joka viidennellä miesopiskelijalla ja naisista reilulla kolmasosalla (AMK-miehet 19,6\%, YO-miehet $24,1 \%$, AMK-naiset 31,2 \%, YO-naiset 39,8\%) (Kuvio 3).

Opiskelijoiden terveystietoisuus eli se, että ajattelee ruokaa hankkiessa ruoan terveellisyyttä usein, oli yhteydessä terveyttä edistävän ruokavalion toteutumiseen sekä miehillä että naisilla ja molemmilla korkeakoulusektoreilla $(\mathrm{p}<0,001$ kaikille ryhmille) (Kuvio 3). Ruoan terveellisyyttä usein ajattelevista miesopiskelijoista noin puolella (AMK 49,2 \%; YO 52,2 \%) ja naisopiskelijoista jopa lähes $60 \% .1 l a$ (AMK 54,5 \%; YO $57,8 \%$ ) toteutui terveyttä edistävä ruokavalio.

Opiskelija- tai työpaikkaravintolassa pääateriansa syövillä opiskelijoilla terveyttä edistävä ruokavalio toteutui useammin kuin jossakin muualla pääateriansa syövillä opiskelijoilla (erot olivat tilastollisesti merkitseviä sekä ammattikorkeakoulu- että yliopisto-opiskelijoilla molemmilla sukupuolilla). Opiskelija- tai työpaikkaravintolassa syöminen oli yhteydessä terveyttä edistävän ruokavalion toteutumiseen useammin yliopisto-opiskelijoilla kuin ammattikorkeakouluopiskelijoilla (miehet: YO 50,6\%, AMK 41,3\%; naiset: YO 58,7 \%, AMK 49,8\%) (Kuvio 3$)$.

Niillä opiskelijoilla, joilla oli lapsia, terveyttä edistävä ruokavalio toteutui lapsettomia useammin. Tilastollisesti ainoa merkitsevä ero oli vain yliopistossa opiskelevien miesten keskuudessa siten, että terveyttä edistä ruokavalio toteutui 40,9 \%:lla lapsettomista miehistä ja 55,7 \%:lla miehistä, joilla oli lapsia $(\mathrm{p}=0,02)$. Opiskelijoiden parisuhteella sen sijaa ei ollut yhteyttä terveyttä edistävän ruokavalion toteutumiseen millään opiskelijaryhmällä. 


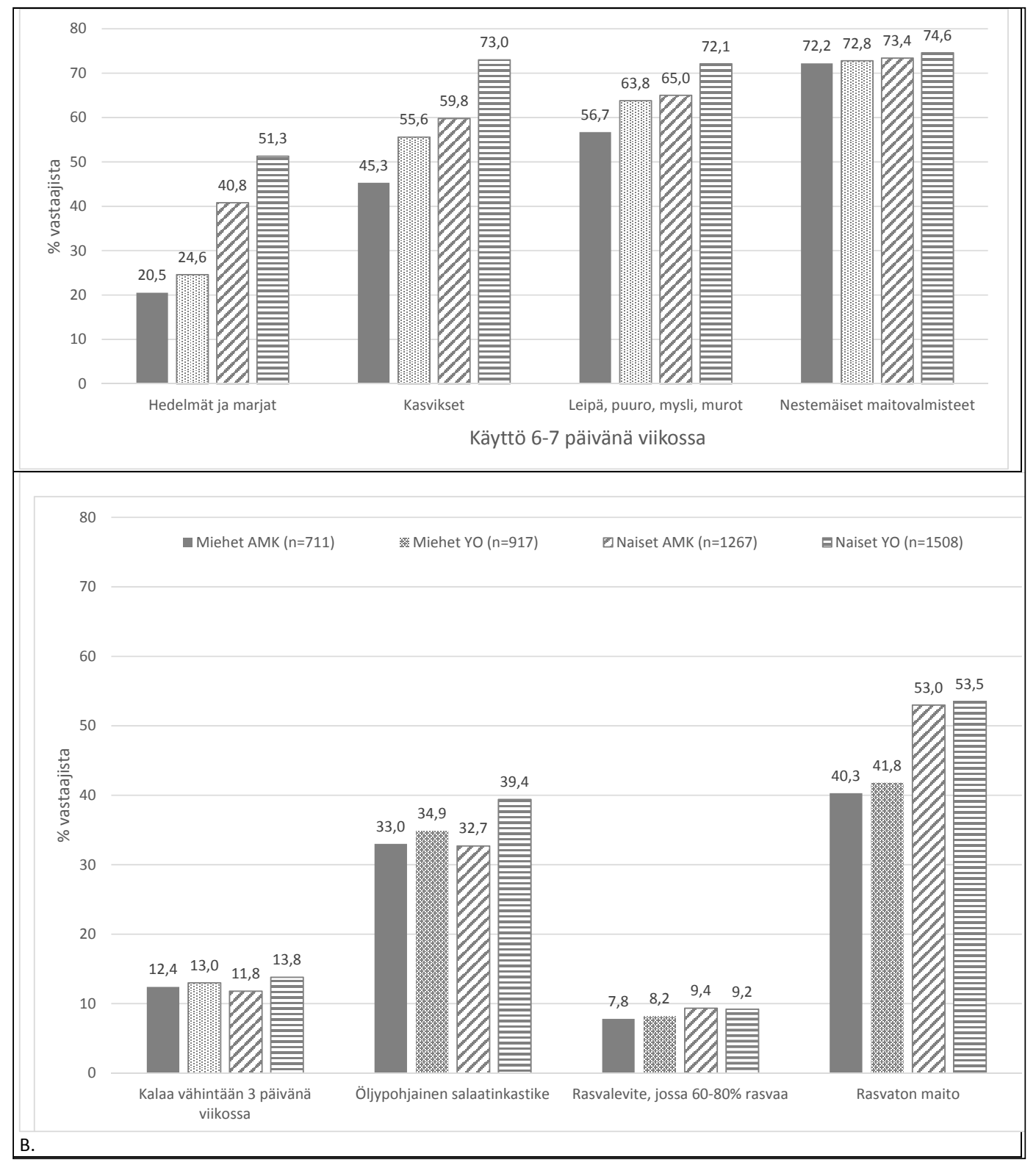

Kuvio 1. Hedelmien, marjojen, kasvisten, viljavalmisteiden sekä maitovalmisteiden syöminen 6-7 päivänä viikossa (A) ja kalan käyttöuseus sekä suosituksen mukaisen salaatinkastikkeen, rasvalevitteen ja maidon pääasiallisesti valitsevien määrä (B) prosentteina sukupuolittain erikseen ammattikorkeakouluissa ja yliopistossa opiskeleville.

Terveyttä edistävä ruokavalio toteutui useammin miehillä, joiden rahojen riittävyys oli erittäin hyvä tai hyvä verrattuna miehiin, joiden toimeentulo vaati säästämistä tai toimeentulo oli niukka ja epävarma $(41,9 \%$ vs. $37,0 \%$; $=0,05)$. Vastaavasti erittäin hyvin tai hyvin toimeentulevilla naisilla terveyttä edistävä ruokavalio toteutui
$52,5 \%: 11$ a verrattuna naisiin, joiden toimeentulo vaati säästämistä tai toimeentulo oli niukka ja epävarma $(45,0 \%$; $<0,001)$. Vanhempien ammattiasema oli yhteydessä terveyttä edistävän ruokavalion toteutumiseen vain yliopistossa opiskelevilla naisilla siten, että se oli vähäisintä $(24,9 \%)$ niillä opiskelijoilla, joiden vanhemmat 


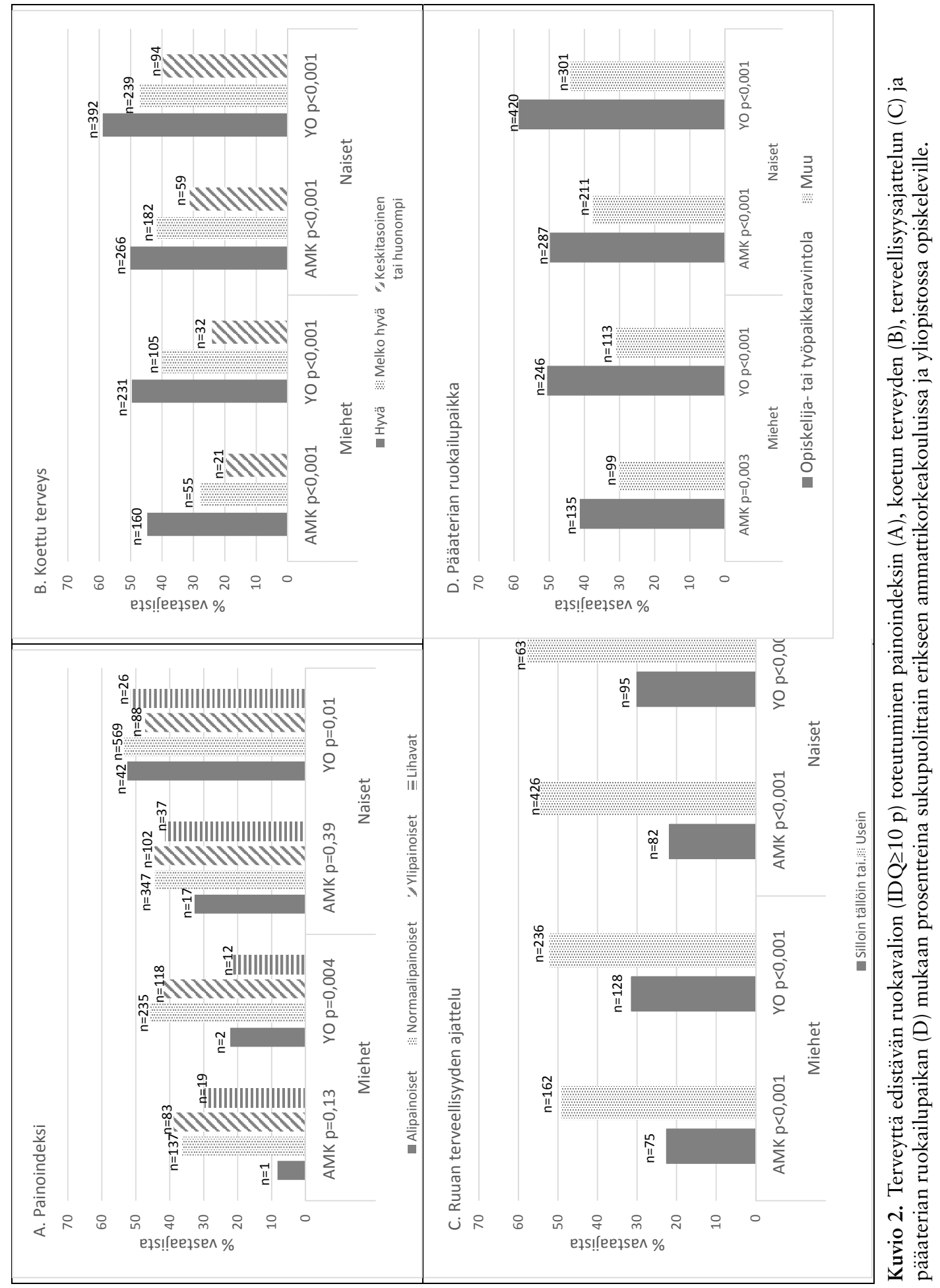


Taulukko 3. Korkeakouluopiskelijoiden terveyttä edistävän ruokavalion (IDQ 0-15) toteutumiseen vaikuttavat taustatekijät. Lineaarinen regressioanalyysi.

\begin{tabular}{|c|c|c|c|c|c|c|}
\hline \multirow[b]{2}{*}{ Selittäjät* } & \multicolumn{3}{|c|}{ Malli 1: selitysaste 20,22} & \multicolumn{3}{|c|}{ Malli $2^{\S}$ : selitysaste 19,73} \\
\hline & $\beta$ & SE & $\mathrm{p}$ & $\beta$ & SE & $\mathrm{p}$ \\
\hline Ikä & 0,02 & 0,01 & 0,14 & 0,02 & 0,01 & 0,14 \\
\hline Sukupuoli, nainen & 0,30 & 0,08 & $<0,001$ & 0,29 & 0,08 & $<0,01$ \\
\hline Korkeakoulu, yliopisto & 0,32 & 0,08 & $<0,001$ & 0,36 & 0,07 & $<0,001$ \\
\hline $\begin{array}{l}\text { Pääateria opiskelija- tai } \\
\text { työpaikkaravintolassa }\end{array}$ & 0,80 & 0,07 & $<0,001$ & 0,83 & 0,07 & $<0,001$ \\
\hline $\begin{array}{l}\text { Ruuan terveellisyyden ajattelu } \\
\text { sen hankintavaiheessa usein }\end{array}$ & 1,61 & 0,08 & $<0,001$ & 1,62 & 0,08 & $<0,001$ \\
\hline $\begin{array}{l}\text { Opiskelijan terveydentila } \\
\text { hyvä }\end{array}$ & 0,94 & 0,11 & $<0,001$ & 0,94 & 0,10 & $<0,001$ \\
\hline $\begin{array}{l}\text { Opiskelijan terveydentila } \\
\text { melko hyvä }\end{array}$ & 0,61 & 0,11 & $<0,001$ & 0,60 & 0,11 & $<0,001$ \\
\hline \multicolumn{7}{|l|}{ Painoindeksi: } \\
\hline alipaino & 0,10 & 0,23 & 0,68 & & & \\
\hline normaalipaino & 0,23 & 0,15 & 0,12 & & & \\
\hline ylipaino & 0,21 & 0,16 & 0,19 & & & \\
\hline Opiskelijalla ei parisuhdetta & 0,05 & 0,08 & 0,51 & & & \\
\hline $\begin{array}{l}\text { Opiskelijalla omia lapsia yksi } \\
\text { tai useampi }\end{array}$ & 0,42 & 0,14 & $<0,01$ & 0,43 & 0,14 & $<0,01$ \\
\hline Opiskelijan toimeentulo hyvä & 0,22 & 0,07 & $<0,01$ & 0,19 & 0,07 & 0,01 \\
\hline \multicolumn{7}{|l|}{ Vanhempien ammattiasema } \\
\hline korkea & 0,27 & 0,26 & 0,29 & & & \\
\hline keskitaso & 0,07 & 0,26 & 0,79 & & & \\
\hline
\end{tabular}

\$vakioitu iällä

olivat työttömänä, eläkkeellä tai opiskelivat itse verrattuna ylimpään ammattiryhmään $(56,4 \%)$.

Lisäksi tässä tutkimuksessa havaittiin, että toimeentulo oli yhteydessä pääaterian syömiseen opiskelija- tai työpaikkaravintolassa. Erittäin hyvin tai hyvin toimeentulevista useimmat söivät opiskelija- tai työpaikkaravintolassa verrattuna niihin, joiden toimeentulo vaati säästämistä tai oli niukka ja epävarma (miehet $56,7 \%$ vs. $50,8 \%$; $\mathrm{p}=0,02$; naiset $53,7 \%$ vs. $47,9 \%$; $\mathrm{p}=0,003)$. Myös painoindeksi oli yhteydessä pääaterian syömiseen opiskelija- tai työpaikkaravintolassa siten, että miehistä harvimmin pääateriansa opiskelija- tai työpaikkaravintolassa söivät alipainoiset $(29,2 \%)$ verrattuna normaalipainoisiin $(56,7 \%)$ ja ylipainoisiin $(50,6 \%$, mukana lihavat), $(\mathrm{p}<0,001)$. Naisilla ei vastaavaa yhtä selkeästi havaittu.

\section{TERVEYTTÄ EDISTÄVÄVÄÄN RUOKAVALIOON YHTEYDESSÄ OLEVAT TEKIJÄT}

Terveyttä edistävän ruokavalion toteutumista ennustavan regressioanalyysin tulokset on esitetty taulukossa 3. Naissukupuoli, opiskelu yliopistossa, ateriointi opiskelijaravintolassa, hyvä toimentulo ja omat lapset olivat yhteydessä hivenen korkeampiin terveyttä edistävän ruokavalion laatupisteisiin. Erityisesti ruoan terveellisyyden ajattelu sen hankintavaiheessa ja oman terveydentilan arvioiminen hyväksi tai melko hyväksi oli edullisesti yhteydessä terveyttä edistävän ruokavalion laatupisteisiin. Sen sijaan opiskelijan painoindeksiluokalla, parisuhteella tai vanhempien ammattiasemalla ei ollut yhteyttä terveyttä edistävän ruokavalion pisteisiin. Kaikki tekijät yhdessä selittivät reilulla $20 \%$ :lla terveyttä edistävän ruokavalion pisteitä. 
Taulukko 4. Korkeakouluopiskelijoiden taustatekijöiden vaikutus epäterveellisen ruokavalion toteutumiselle (IDQ < 10) prosenttiosuuksina (n). Binaarinen logistinen regressioanalyysi; riskisuhteet $(\mathrm{OR})$ ja $95 \%$ :n luottamusvälit (LV).

\begin{tabular}{|c|c|c|c|c|c|}
\hline \multirow[b]{2}{*}{ Sukupuoli N=4112 } & \multirow{2}{*}{$\frac{\text { IDQ }<10}{\%(n)}$} & \multicolumn{2}{|c|}{ Vakioimaton } & \multicolumn{2}{|c|}{ Vakioitu $^{\S}$} \\
\hline & & OR $(95 \% \mathrm{LV})$ & p-arvo & OR $(95 \% \mathrm{LV})$ & p-arvo \\
\hline Nainen & $51,9(1337)$ & & & & \\
\hline Mies & $60,4(926)$ & $1,41(1,2-1,6)^{* * * *}$ & $<0,001$ & & \\
\hline \multicolumn{6}{|l|}{ Korkeakoulu $\mathrm{N}=4112$} \\
\hline Yliopisto & $51,8(1180)$ & & & & \\
\hline Ammattikorkeakoulu & $59,1(1083)$ & $1,3(1,2-1,5)$ & $<0,001$ & & \\
\hline \multicolumn{6}{|l|}{$\begin{array}{l}\text { Pääaterian ruokailupaikka } \\
\mathrm{N}=4043\end{array}$} \\
\hline Opiskelija- tai työpaikkaravintola & $48,3(1016)$ & & & & \\
\hline Muu & $62,7(1215)$ & $1,8(1,6-2,0)$ & $<0,001$ & $1,8(1,6-2,1)$ & $<0,001$ \\
\hline \multicolumn{6}{|l|}{$\begin{array}{l}\text { Ruoan terveellisyyden ajattelu } \\
\mathrm{N}=4091\end{array}$} \\
\hline Usein & $45,2(1200)$ & & & & \\
\hline Silloin tällöin tai harvemmin & $73,5(1056)$ & $3,4(2,9-3,9)$ & $<0,001$ & $3,2(2,8-3,7)$ & $<0,001$ \\
\hline \multicolumn{6}{|l|}{ Koettu terveys N=4090 } \\
\hline Hyvä & $48,1(972)$ & & & & \\
\hline Melko hyvä & $58,6(823)$ & $1,5(1,3-1,8)$ & $<0,001$ & $1,6(1,4-1,8)$ & $<0,001$ \\
\hline Keskitasoinen tai huonompi & $69,0(459)$ & $2,4(2,0-2,9)$ & $<0,001$ & $2,5(2,1-3,0)$ & $<0,001$ \\
\hline \multicolumn{6}{|l|}{ Painoindeksi $\mathrm{N}=4084$} \\
\hline Alipaino & $59,5(91)$ & $1,3(0,9-1,8)$ & 0,11 & $1,4(1,0-1,9)$ & 0,06 \\
\hline Normaalipaino & $52,9(1446)$ & & & & \\
\hline Ylipaino & $57,2(523)$ & $1,2(1,0-1,4) *$ & 0,02 & $1,1(0,9-1,3)$ & 0,23 \\
\hline Lihavuus & $66,8(189)$ & $1,8(1,4-2,3)$ & $<0,001$ & $1,7(1,3-2,2)$ & $<0,001$ \\
\hline \multicolumn{6}{|l|}{ Parisuhde $\mathrm{N}=4077$} \\
\hline Parisuhteessa & $54,4(1452)$ & & & & \\
\hline Ei parisuhteessa & $55,8(785)$ & $1,1(0,9-1,2)$ & 0,39 & $1,0(0,9-1,2)$ & 0,93 \\
\hline \multicolumn{6}{|l|}{ Lapsia $N=3825$} \\
\hline Yksi tai useampia & $45,5(147)$ & & & & \\
\hline Ei lapsia & $55,9(1956)$ & $1,5(1,2-1,9)$ & $<0,001$ & $1,5(1,2-2,0)$ & $<0,001$ \\
\hline \multicolumn{6}{|l|}{ Toimeentulo $\mathrm{N}=4088$} \\
\hline Erittäin hyvä tai hyvä & $51,8(960)$ & & & & \\
\hline $\begin{array}{l}\text { Vaatii säästämistä tai on niukka ja } \\
\text { epävarma }\end{array}$ & $57,7(1290)$ & $1,3(1,1-1,4)$ & $<0,001$ & $1,3(1,1-1,4)$ & $<0,001$ \\
\hline \multicolumn{6}{|l|}{$\begin{array}{l}\text { Vanhempien ammattiasema } \\
\mathrm{N}=3949\end{array}$} \\
\hline $\begin{array}{l}\text { Yrittäjä, ylempi tai alempi } \\
\text { toimihenkilö }\end{array}$ & $52,3(1036)$ & & & & \\
\hline $\begin{array}{l}\text { Työntekijä, maanviljelijä, } \\
\text { pienyrittäjä }\end{array}$ & $57,5(1085)$ & $1,6(1,0-2,6)$ & 0,05 & $1,6(1,0-2,6)$ & 0,05 \\
\hline Työtön, opiskelija, eläkeläinen & $63,7(51)$ & $1,2(1,1-1,4)$ & $<0,01$ & $1,2(1,1-1,4)$ & $<0,01$ \\
\hline
\end{tabular}

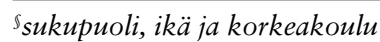


Tulokset eivät juurikaan muuttuneet analyysin toisessa vaiheessa, jossa mukana pidettiin ensimmäisen mallin tilastollisesti merkitsevät muuttujat käyttäen vakioivana tekijänä ikää. Taustatekijöistä terveyttä edistävän ruokavalion korkeampia pisteitä selittävät erityisesti ruoan terveellisyyden ajattelu $(\beta=1,62, p<0,001)$, oman terveydentilan arviointi hyväksi $(\beta=0,94$, $p<0,001)$ ja ateriointi opiskelija- tai työpaikkaravintolassa $(\beta=0,83, p<0.001)$. Selitysaste ei juurikaan muuttunut aiemmasta ollen 19,7\%.

\section{EPÄTERVEELLISEN RUOKAVALION RISKI}

Ammattikorkeakouluopiskelijoilla oli suurempi riski kuin yliopisto-opiskelijoilla siihen, että terveyttä edistävä ruokavalio ei toteudu, samoin miehillä naisiin verrattuna (Taulukko 4). Niillä opiskelijoilla, jotka eivät ajatelleet ruoan terveellisyyttä usein ruokaa hankkiessaan, oli yli kolme kertaa suurempi riski epäterveelliseen ruokavalioon terveystietoisiin opiskelijoihin verrattuna (Taulukko 4).

Vain melko hyvä tai keskitasoa huonompi koettu terveys lisäsivät epäterveellisen ruokavalion riskiä 1,5-2,4-kertaiseksi. Samoin epäterveellisen ruokavalion riski oli suurentunut niillä, joiden toimeentulo vaati säästämistä tai oli niukka ja epävarma verrattuna erittäin hyvin tai hyvin toimeentuleviin (Taulukko 4). Muualla kuin opiskelija- tai työpaikkaravintolassa pääateriansa syövillä opiskelijoilla oli lähes kaksinkertainen epäterveellisen ruokavalion riski ravintolassa syöviin verrattuna. Ylipainoisilla (1,2- kertainen) ja lihavilla (1,8- kertainen) oli suurempi riski epäterveelliseen ruokavalioon normaalipainoisiin verrattuna $(p<0,001)$. Yhteys säilyi sukupuolen, iän ja korkeakoulun suhteen vakioidussa mallissa vain lihavuuden osalta (riski oli 1,7-kertainen) ( $\mathrm{p}<0,001)$. Opiskelijat, joilla ei ollut lapsia, riski epäterveelliseen ruokavalioon oli suurempi yhden tai useamman lapsen omaaviin verrattuna (OR 1,5; $<<0,001)$. Vanhempien alempi sosioekonominen asema oli yhteydessä epäterveellisen ruokavalion riskiin (OR 1,2-1, 6-kertainen; $\mathrm{p}<0,05$ ).

\section{POHDINTA}

Naisten ja yliopisto-opiskelijoiden ruokailutottumukset olivat tämän tutkimuksen mukaan lähempänä ravitsemussuosituksia kuin miesten ja am- mattikorkeakouluopiskelijoiden. Tulokset ovat linjassa aiemman tutkimustiedon kanssa (22-24). Terveellisen ruokavalion toteutuminen oli yhteydessä parempaan terveystietoisuuteen ja hyvään koettuun terveyteen sekä hyvään toimeentuloon. Lisäksi opiskelija- tai työpaikkaravintolassa nautittu pääateria oli yhteydessä terveyttä edistävän ruokavalion toteutumiseen ja parempiin ruokatottumuksiin. Aiemmissa tutkimuksissa on saatu samansuuntaisia tuloksia terveystietoisuuden, toimeentulon ja pääaterian syöntipaikan yhteydestä ruokavalion laatuun $(5,12,16)$.

Terveystietoisuus eli se, ajatteleeko ruokaa hankkiessa ruoan terveellisyyttä, oli merkittävin korkeakouluopiskelijoiden ruokavalion laatuun yhteydessä oleva tekijä. Jo aiemmin on havaittu, että suosituksenmukaisimmat ruokatottumukset omaavista noin $74 \%$ ajatteli usein ruuan terveellisyyttä sitä ostaessaan, kun vastaava osuus epäterveellisten tottumusten omaavien ryhmässä oli vain $30 \%$ (22). Terveystietoisilla opiskelijoilla ravitsemussuositusten mukaiset, terveyttä edistävät ruokavalinnat toteutuivat useammin, ja he söivät pääateriansa useammin opiskelijatai työpaikkaravintolassa kuin muut. Kysymyslomakkeessa päivän pääaterian syöntipaikkaa kysyttäessä opiskelija- ja työpaikkaravintola olivat samassa kohdassa, koska tavoitteena oli selvittää nimenomaan joukkoruokailussa syötyä päivän pääateriaa eikä erikseen ei kysytty tuetun opiskelijalounaan syömistä (15). Sukupuolten väliset erot ruokavalion laadussa selittyvät varmasti osittain sillä, että naiset ajattelivat ruoan terveellisyyttä useammin kuin miehet. Mielenkiintoista on kuitenkin myös se, että terveystietoisuus eli se, miten usein ajatteli ruuan terveellisyyttä sen hankintavaiheessa, ei miehillä johtanut terveyttä edistävän ruokavalion toteutumiseen yhtä usein kuin naisilla. Koska yliopistossa opiskelu on yhteydessä terveystietoisuuteen etenkin naisilla (15), myös korkeakoulusektorien väliset erot ruokavalion laadussa selittynevät osittain terveystietoisuuden välityksellä. Miehistä yliopistossa opiskelevat söivät pääateriansa useammin opiskelija- tai työpaikkaravintolassa kuin ammattikorkeakoulussa opiskelevat. Naisilla vastaavaa eroa korkeakoulujen välillä ei havaittu. Koska terveyttä edistävä ruokavalio toteutui useammin pääateriansa opiskelija- tai työpaikkaravintolassa syövillä yliopisto-opiskelijoilla 
kuin ammattikorkeakouluopiskelijoilla, eri korkeakoulujen opiskelijaravintoloiden tarjoamien aterioiden laadussa saattaa myös olla eroa. Näin siitäkin huolimatta, että Kelan avustukseen oikeuttavien opiskelija-aterioiden tarjonnasta on annettu laatukriteerit, joiden toteutumista seurataan pääosin omavalvonnalla, mutta myös tarkastuksin (13). On toki mahdollista, että ammattikorkeakoulu- ja yliopisto-opiskelijat valitsevat tarjonnasta eri tavoin. Aiempaa tutkimustietoa aiheesta ei kuitenkaan ole.

Korkeakouluopiskelijoiden toimeentuloa tarkastelleen tutkimuksen mukaan puolella suomalaisista korkeakouluopiskelijoista oli vaikeuksia saada rahat riittämään ja noin puolet kävi ansiotyössä opintojen ohella (25). Yliopisto-opiskelijoiden rahatilanne oli korkeakouluopiskelijoiden terveystutkimuksen mukaan parempi kuin ammattikorkeakouluopiskelijoiden (15). Heikko toimeentulo on yhteydessä vähemmän terveellisiin ruokailutapoihin (12) . Rahojen riittävyyden hyväksi arvioivilla naisilla, joilla oli mahdollisuus työpaikkaruokailuun ja jotka tekivät säännöllistä työtä, suositusten mukainen ruokavalio toteutui useammin kuin niillä samassa tilanteessa olevilla naisilla, jotka arvioivat rahojen riittävyyden huonoksi (4). Miehillä vastaavaa yhteyttä rahojen riittävyyden ja suositusten mukaisen ruokavalion toteutumisen välillä ei havaittu. Tämän tutkimuksen mukaan myös korkeakouluopiskelijoilla ruokavalion laatu oli sitä parempi, mitä parempi oli toimeentulo. Toisaalta opiskelijoilla, joiden toimeentulo vaati säästäväisyyttä, terveyttä edistävä ruokavalio toteutui lähes yhtä usein kuin hyvin toimeentulevilla. Pääaterian syöntipaikka saattaa selittää ainakin osittain toimeentulon yhteyttä opiskelijoiden ruokavalion laatuun, sillä tämän tutkimuksen mukaan parempi toimeentulo oli yhteydessä pääaterian syömiseen opiskelija- tai työpaikkaravintolassa. Aiempaa tutkimustietoa korkeakouluopiskelijoiden toimeentulon, pääaterian syöntipaikan ja ruokavalion laadun yhteydestä ei ole.

Painoindeksin merkitys terveyttä edistävän ruokavalion toteutumiselle ei näyttäisi olevan opiskelijoilla kovinkaan merkittävä. Tässä tutkimuksessa ylipainoisten ja lihavien ruokavalion laatu oli heikompi kuin normaalipainoisten, mutta alipainoisuus ei ollut yhteydessä ruokavalion laatuun. Toisaalta pitää muistaa, että normaalipainosta poikkeava painoindeksi voi ruokailutottumuksia koskevissa kyselytutkimuksissa johtaa yli- tai aliraportointiin (26). Myös paino- ja pituustiedot ovat tässä aineistossa tutkittavien itse raportoimia. Kyselytutkimuksille tyypillinen painon aliraportointi ja pituuden yliraportointi johtaa todellisuutta alhaisempaan laskennalliseen painoindeksiin (25). Lisäksi painoindeksin käyttö ylipainon arvioinnissa suuren lihasmassan omaavilla saattaa olla ongelmallista, sillä painoindeksi ei huomioi lihasmassan määrää (28). Tämä saattaa selittää osittain sen, miksi normaalipainoisten ja ylipainoisten miesopiskelijoiden ruokavalion laatu ei juuri eronnut toisistaan. Alipainoisten osuus oli verraten pieni eikä siten selittänyt merkittävästi epäterveellisen ruokavalion riskiä huolimatta siitä, että riski oli lähes yhtä suuri kuin ylipainoisilla. Tulokseen voi vaikuttaa myös se, että korkeakouluopiskelijoista vain hyvin harva (noin 0,5\%) kokee olevansa selvästi alipainoinen ja suuri osa (yli $80 \%$ ) arvioi oman suhtautumisensa ruokaan normaaliksi (15).

Korkeakouluopiskelijoiden terveystutkimuksen otoksessa oli mukana lähes yhtä paljon yliopisto- ja ammattikorkeakouluopiskelijoita (15). Otanta toteutettiin opiskelupaikkakunnittain tai korkeakouluittain ositettuna satunnaisotantana, jotta otos olisi mahdollisimman edustava. Tutkimukseen vastanneet edustivat hyvin kohdejoukkoa muiden taustamuuttujien kuin sukupuolen osalta, sillä miesten vastausaktiivisuus oli naisia merkittävästi pienempi. Tutkimukseen vastanneet miehet ovat todennäköisesti olleet motivoituneempia ja terveydestään enemmän kiinnostuneita kuin vastaamatta jättäneet miehet. Toisaalta sama oletus pätee myös tutkimukseen vastanneisiin naisiin. Koska vastanneiden valikoituminen on siis todennäköisesti samaan suuntaan vinoutunut sekä miehillä että naisilla, voidaan ajatella, että se ei merkittävästi vaikuta tutkimuksen tuloksiin.

Korkeakouluopiskelijoiden terveystutkimuksesta vuodelta 2008 tehdyn katoanalyysin mukaan vastaamattomien miesten keskuudessa ilmeni, ettei eroja ollut ylipainoisuudessa, suhtautumisessa ruokaan tai ruuan terveellisyyden ajattelussa (23). Toisaalta selvisi, että kyselyyn vastanneet kokivat terveydentilansa huonomaksi kuin kyselyyn vastaamatta jättäneet. He olivat myös muita yleisemmin olleet kiusattuja ja harrastivat kuntoliikuntaa harvemmin. 
Koko maan opiskelijoista tilastokeskuksen koulutustilastojen mukaan vuonna 2014 kävi opintojen ohella töissä hieman yli puolet (29), kun taas tässä tutkimuksessa opintojen ohella työssä kävi jopa yli $60 \%$ opiskelijoista. Kyseinen tilasto sisältää tiedot yli 18-vuotiaiden lukiokoulutuksen, ammatillisen koulutuksen, ammattikorkeakoulukoulutuksen sekä yliopistokoulutuksen opiskelijoiden työssäkäynnistä eikä siksi ole täysin vertailukelpoinen tämän tutkimuksen aineiston kanssa. Opetusministeriön opiskelijatutkimuksen (25) mukaan suomalaisista korkeakouluopiskelijoista $53 \%$ on naisia ja $47 \%$ miehiä. Kaikkien opiskelijoiden keskimääräinen ikä oli 25 vuotta. Luvut kuvaavat hyvin myös tähän tutkimukseen osallistuneita.

Korkeakouluopiskelijoiden ruokavalion laatua ja siihen yhteydessä olevia tekijöitä ei ole aiemmin juurikaan tutkittu. Tutkimuksessa käytetty ravintomittari antaa uudenlaisen mahdollisuuden tarkastella ravitsemussuositusten mukaisen terveyttä edistävän ruokavalion toteutumista sekä yksilö- että ryhmätasolla. Koska ravintomittari on kehitetty ennen uusimpien ravitsemussuositusten julkaisua (2), siinä ei ole voitu huomioida uusinta lihankäytön suositusta. Silti voidaan todeta, että ravintomittari (IDQ) korkeakouluopiskelijoiden ruokavalion laadun tarkastelussa toimi kuten sen oli suunniteltu toimivan (20). Toisin sanoen mittari antaa hyvän yleiskuvan korkeakouluopiskelijoiden terveyttä edistävän ruokavalion toteutumisesta. Tämän tutkimuksen heikkoutena voidaan nähdä se, että käytetyn ruokavalion laatumittarin avulla ei kuitenkaan ole mahdollista saada tarkkaa tietoa yksittäisten ruokien käyttömääristä tai -tiheydestä. Mittarin ongelmana voidaan nähdä myös se, että käytettäessä sitä kaksiluokkaisena, raja-arvon molemmin puolin saattaa olla paljon tutkittavia ja pienikin ero indeksissä johtaa tutkittavan päätymisen joko terveyttä edistävän ruokavalion tai epäterveellisen ruokavalion ryhmään. Käytännössä hyvin pienillä eroilla raja-arvon molemmin puolin ei ole juurikaan merkitystä, mutta tämä tapa mahdollistaa vertailun ryhmätasolla. On myös mahdollista, että ruuan terveellisyyttä erityisesti ajattelevat opiskelijat pyrkivät antamaan sosiaalisesti hyväksyttävämpiä vastauksia. Tosin tämä on mahdollista kaikkien opiskelijoiden keskuudessa. Tutkimuksen vahvuutena voidaankin nähdä se, että aineisto perustuu vakiintuneeseen ja laajaan kyselytutkimukseen, jossa aiemmin on toteutettu myös katoanalyysi.

Opiskelijoiden taloudelliset vaikeudet johtavat usein siihen, että ruokavalinnat tehdään suurimmaksi osaksi hinnan perusteella. Tilastokeskuksen tietojen mukaan opiskelijakotitalouksien kulutus oli vuonna 2012 alemmalla tasolla kuin vuonna 1990, ja noin $60 \%$ :lla oli vaikeuksia saada rahat riittämään (30). Asumismenojen jälkeen toiseksi eniten opiskelijakotitalouksilta kului rahaa liikenteeseen ja kolmanneksi eniten ruokaan. Kotitalouksien pienituloisin viidennes, joihin opiskelijakotitalouksista suuri osa kuuluu, kuluttaa asumiseen ja ruokaan suhteellisesti enemmän kuin muut tuloviidennekset (31). Julkisessa keskustelussa painottuu usein se, että niin sanottu terveellinen ruoka on kallista. Väittämästä ei kuitenkaan ole tieteellistä näyttöä.

Monet aikuisiän terveyteen vaikuttavat elintavat vakiintunevat jo nuorena tai nuorena aikuisena, ja aiemmissa tutkimuksissa on havaittu, että vanhempien koulutus ja ruokakäyttäytyminen on ollut yhteydessä lasten parempaan ruokavalioon $(31,32)$. On todettua, että alempaan sosioekonomiseen asemaan kuuluvat noudattavat suositusten mukaisia ruokatottumuksia heikommin kuin muut (33). Tässä tutkimuksessa sosioekonomista asemaa selvitettiin kysymyksellä vanhempien ammattiasemasta, kun vastaaja oli 15 -vuotias. Kysymyksen muotoilu herätti vastaajissa jonkin verran hämmennystä (15). Myös vastausten tulkintapulmia lisäsi se, että vanhimmat opiskelijat olivat jo 35-vuotiaita. Opiskelijoilla on havaittu runsaastikin muutoksia ruokatottumuksissa viisivuotisena seurantaaikana (34): opiskelun alussa epäterveellisesti syövistä miehistä $60.8 \%$ ja naisista $48.8 \%$ oli korjannut ruokavaliotaan terveellisempään suuntaan opiskelun kuluessa. Toisaalta havaittiin epäterveellisesti syövien joukosta isohko osa (27,5 \% miehistä ja 37,4 \% naisista), joka pysyi myöhemmissäkin seurannoissa samassa ryhmässä. Odottamaton havainto oli se, että alun perin väliryhmään kuuluneista naisopiskelijoista suurempi osa oli siirtynyt epäterveellisesti syöviin kuin terveellisesti syöviin.

On mahdollista, että lapsiperheiden vanhemmat kiinnittävät myös omiin ruokatottumuksiinsa enemmän huomiota, kun perheessä on lapsia. Odotuksen mukaisesti havaittiin, että niillä 
opiskelijoilla, joilla oli lapsia, terveyttä edistävä ruokavalio toteutui lapsettomia useammin. Parisuhde, joka nuorilla aikuisilla saattaa olla vähemmän vakiintunut, ei sen sijaan ollut yhteydessä terveyttä edistävän ruokavalion toteutumiseen vastoin aiempia tutkimuksia $(19,35)$, ei myöskään epäterveellisen ruokavalion riskiin.

Opiskelijoiden terveystietoisuuden lisäämisellä, terveellisiin valintoihin motivoimalla sekä toimeentulon takaamisella voitaisiin parantaa opiskelijoiden mahdollisuutta tehdä terveydelle edullisia ruokavalintoja. Myös opiskelijaravintoloissa tarjottavan ruuan ravitsemuksellisen laadun parantaminen auttaisi edistämään niissä ruokailua. Lisäkeinona voitaisiin ottaa käyttöön palveluseteleitä, joilla pääsisi ruokailemaan laatukriteerit täyttäviin ravintoloihin.

Myös muut tekijät saattavat heijastua tuloksiin. Esimerkiksi elämänhallinnan ja henkisen hyvinvoinnin ongelmat voivat heijastua myös ruokakäyttäytymiseen. Opiskelijoista $7 \%$ :lla on todettu masennus ja $5 \%: 11$ a ahdistuneisuushäiriö, 12 \% kokee psyykkisiä oireita päivittäin ja runsasta stressiä lähes kolmannes (15). Depressiiviset opiskelijat eivät välttämättä jaksa lähteä opiskelijaravintoloihin, ahdistuneet ja jännittävät opiskelijat eivät uskalla niihin mennä. Jos opiskelijalla on toimeentulopulmiakin, ratkaisuksi tarjoutuu pihistäminen ruokailusta.

Tiivistäen voi sanoa, että terveystietoisuus oli merkittävin tekijä opiskelijoiden terveyttä edistävän ruokavalion toteutumisessa erityisesti yliopisto-opiskelijoilla ja naisilla. Koska etenkin opiskelijoiden terveystietoisuus näyttäisi olevan vahvasti yhteydessä terveyttä edistävän ruoka- valion toteutumiseen ja siten parempaan ruokavalion laatuun, olisi tärkeää saada yhä useampi opiskelija ajattelemaan ruoan terveellisyyttä jo ruoanhankintatilanteessa. On syytä panna merkille, että opiskelijat myös toivovat usein (miehistä 5-6\% ja naisista $16 \%$ ) apua ravitsemusasioihin (15). Jatkotutkimuksissa olisi tarkennettava opiskelijoiden toimeentulon ja sosioekonomisen taustan osuutta pääaterian syöntipaikan valinnassa esimerkiksi rekisteriaineistoja hyväksikäyttäen. Jo nyt esitetyistä tuloksista voitaneen päätellä, että terveys- ja ravitsemuskasvatus on tärkeää erityisesti ammattikorkeakouluissa ja miesopiskelijoiden keskuudessa.

\section{KIRJOITTAJIEN KONTRIBUUTIOT}

Kaikki kirjoittajat ovat vastuussa tässä käsikirjoituksessa esitettyjen tulosten raportoinnista, aineiston analyyseistä sekä tulosten tulkinnasta ja käsikirjoituksen työstämisestä. Työnjaosta voidaan tarkemmin todeta seuraavaa: SL on paneutunut erityisesti taustakirjallisuuteen ja taulukoiden ja kuvien työstämiseen. KK on vastannut aineiston keruusta kokonaisuudessaan. JM on vastannut tilastollisten menetelmien valinnasta ja JI on huolehtinut kaikista tilastollisista analyyseistä ja tulosten tarkistamisesta. HL on vastannut käsikirjoituksen viimeistelystä ja tulosten tarkistamisesta. Kaikilla kirjoittajilla on ollut riittävästi pääsy tietoihin sekä tilastollisiin analyyseihin ja näin mahdollisuus tarkistaa käsikirjoituksen tieteellinen luotettavuus. Jokainen kirjoittaja on hyväksynyt lopullisen käsikirjoituksen ennen sen toimittamista arviointiin.

Lagström H, Luoto S, Mäkelä J, lirola J, Kunttu K. Diet related, health promoting factors among university level students. Sosiaalilääketieteellinen aikakauslehti - Journal of Social Medicine 2017:54: 104-133

The Finnish Studen Health Survey has been carried out since 2000. This survey focuses on Finnish students (Bachelor's or Master's degree) under the age of 35 . Since 2008 survey has included also students of universities of applied sciences. In year 2012 the survey focused also on dietary quality among students. The aim of this scientific article is to describe the dietary quality and adherence to nutrition recommendations among students. The objective is to analyze the adherence to dietary recommendations its associations with BMI, health-orientation, self-perceived health, incomes and meal place by gender. The study was conducted in year 2012 with a questionnaire which was delivered by mail to all the students under the age of 35 years. Questionnaire was also available electronically. Dietary quality was assessed with Index of Diet Quality (IDQ) that has been previously validated against 7-day food records. Total of $4403(44 \%)$ students answered to the questionnaire.Women were more likely to adhere to nutrition recommendations compared to men. 
University students had higher dietary quality than the students from Universities of applied sciences. Overweight and obese students had higher risk for poor diet quality and they adhered to nutrition recommendations more poorly than normal weight students. Higher dietary quality was associated with studying at University, being normal weight, being health-orientated, having good self-perceived health, having stable incomes and eating lunches or dinners at student or workplace restaurants. In conclusion, the main factors associated with adherence to dietary recommendations among students in Finland were gender and being a University student. Health-orientation was the strongest factor associated with better dietary quality. Being overweight, obese or underweight were associated with lower dietary quality. Eating main meals at student or workplace restaurant was statistically significantly associated with adherence to dietary recommendations and therefore student's meals at those restaurants should be continued to support.

Keywords: Students Health Dietary quality Eating habits

\section{LÄHTEET}

1. Valtioneuvoston periaatepäätös terveyttä edistävän liikunnan ja ravinnon kehittämislinjoista. Sosiaalija terveysministeriön julkaisuja, 2008:10. http://urn.fi/URN:NBN:fi-fe201504224909

2. Valtion ravitsemusneuvottelukunta. Terveyttä ruoasta. Suomalaiset ravitsemussuositukset 2014. Helsinki: Juvenes Oy, 2014.

3. Palosuo H, Koskinen S, Lahelma E, ym. (toim.) Terveyden eriarvoisuus Suomessa. Sosioekonomisten terveyserojen muutokset 19802005. Sosiaali- ja terveysministeriön julkaisuja, 2007:23.

4. Roos E, Sarlio-Lähteenkorva S, Lallukka T. Having lunch at a staff canteen is associated with recommended food habits. Public Health Nutr 2004;7:53-61. https://doi.org/10.1079/PHN2003511

5. Helldán A, Raulio S, Kosola M, ym. (toim). Finravinto 2012 -tutkimus - The National FINDIET 2012 Survey. Helsinki: THL Raportti 16/2013.

6. Raulio S, Roos E, Prättälä R. School and workplace meals promote healthy food habits. Public Health Nutr 2010;13:987-92. https:/doi.org/10.1017/S1368980010001199

7. Hoppu U, Kujala J, Lehtisalo J, ym. Yläkoululaisten ravitsemus ja hyvinvointi: Lähtötilanne ja lukuvuonna 2007-2008 toteutetun interventiotutkimuksen tulokset. Kansanterveyslaitos, 2008. http://urn.fi/URN:NBN:fi-fe201204193417

8. Lehtisalo J, Erkkola M, Tapanainen H, ym. Food consumption and nutrient intake in day care and at home in 3-year-old Finnish children. Public Health Nutr 2010;13:957-64. https://doi.org/10.1017/S1368980010001151

9. Lallukka T, Lahti-Koski M, Ovaskainen M-L. Vegetable and fruit consumption and its determinants in young Finnish adults. Scand J Nutr 2001;45:120-6. https://doi.org/10.3402/fnr.v45i0.1792

10. Raulio S, Roos E, Ovaskainen M, ym. Food use and nutrient intake at worksite canteen or in packed lunches at work among Finnish employees. J Foodserv 2009;20:330-41. https://doi.org/10.1111/j.1748-0159.2009.00157.x

11. Lindblom T, Sarpila O. Koulutus ja tulotaso vaikuttavat ruokailutottumuksiin. Tilastokeskus, Hyvinvointikatsaus 4/2014:33-8.

12. Lallukka T, Laaksonen M, Rahkonen O, ym. Multiple socio-economic circumstances and healthy food habits. Eur J Clin Nutr 2007;61: 701-10. https://doi.org/10.1038/sj.ejcn.1602583

13. Kela ja Valtion ravitsemusneuvottelukunta. Korkeakouluopiskelijoiden ruokailusuositus - terveyttä ruoasta. Helsinki: Kela, 2016.

14. Vikstedt T, Raulio S, Helakorpi S, Jallinoja P, Prättälä R (toim). Työaikainen ruokailu Suomessa 2008-2010 - Ruokapalveluiden seurantaraportti 4. THL Raportti 23/2012. http://urn.fi/URN:ISBN:978-952-245-621-2.

15. Kunttu K, Pesonen T. Korkeakouluopiskelijoiden terveystutkimus 2012. Helsinki: Ylioppilaiden terveydenhoitosäätiön tutkimuksia 47; 2013.

16. Deshpande S, Basil MD, Basil DZ. Factors Influencing healthy eating habits among college students: an application of the health belief model. Health Mark Q 2009;26:145-64. https://doi.org/10.1080/07359680802619834

17. Lagström H, Talvia S, Pahkala K, ym. Toisen asteen koulutusvalinnan yhteys nuorten ruokatottumuksiin - STRIP -projekti. Sos Lääk Aikak 2012;49:118-131.

18. Menozzi D, Sogari G, Mora C. Explaining Vegetable Consumption among Young Adults: An Application of the Theory of Planned Behaviour. Nutrients 2015;7:7633-50. https://doi.org/10.3390/nu7095357

19. Cornelius T, Desrosiers A, Kershaw T. Spread of health behaviors in young couples: How relationship power shapes relational influence. Soc Sci Med 2016;165:46-55. https://doi.org/10.1016/j.socscimed.2016.07.030 
20. Leppälä J, Lagström H, Kaljonen A, ym. Construction and evaluation of a self-contained index for assessment of diet quality. Scand J Public Health 2010;38:794-802. https://doi.org/10.1177/1403494810382476

21. Mäkelä J, Laitinen K. Uusi ruokavalion laadun mittari ravitsemusohjauksen tueksi. Suomen Lääkärilehti 2012;67:161-3.

22. Kunttu K. Korkeakouluopiskelijoiden terveyskäyttäytyminen ja sosiaaliset suhteet. Helsinki: Kansaneläkelaitos, Sosiaali- ja terveysturvan tutkimuksia 28; 1997.

23. Kunttu K, Pesonen T. Korkeakouluopiskelijoiden terveystutkimus 2008. Helsinki: Ylioppilaiden terveydenhoitosäätiön tutkimuksia 45; 2009.

24. Lagström H. Opiskelijoiden ruokatottumukset. Kirjassa: Kunttu K, Komulainen A, Makkonen K, Pynnönen P (toim). Opiskeluterveys. Helsinki: Duodecim 2011:190-194.

25. Opiskelijatutkimus 2014 - Korkeakouluopiskelijoiden toimeentulo ja opiskelu. Opetus- ja kulttuuriministeriön julkaisuja, 2014:10.

26. Weber JL, Reid PM, Greaves KA, ym. Validity of self-reported energy intake in lean and obese young women, using two nutrient databases, compared with total energy expenditure assessed by doubly labeled water. Eur J Clin Nutr 2001;55:940-50. https://doi.org/10.1038/sj.ejcn.1601249

27. Lassale C, Péneau S, Touvier M, ym. Validity of web-based self-reported weight and height: results of the Nutrinet-Santé study. J Med Internet Res 2013;15:e152. DOI:10.2196/jmir.2575 https://doi.org/10.2196/jmir.2575

28. Fogelholm M. Lihavuuden arviointi. Kirjassa: Mustajoki P, Fogelholm M, Rissanen A, Uusitupa M, toim. Lihavuus - ongelma ja hoito. Kustannus Oy Duodecim 2006, s. 49-61.

29. Suomen virallinen tilasto (SVT): Opiskelijoiden työssäkäynti [verkkojulkaisu].ISSN=1798-999X. Helsinki: Tilastokeskus [viitattu: 10.8.2016]. Saantitapa: http://www.stat.fi/til/opty/index.html

30. Tilastokeskus. Hyvinvointikatsaus 4/2014 Teema: Kulutus. Joulukuu 2014 (luettu 11.8.2016 http://tilastokeskus.fi/tup/hyvinvointikatsaus/ hyka_2014_04.html)

31. Erkkola M, Kyttälä P, Kautiainen S, ym. Alle kouluikäisten ruoankäytön väestöryhmittäiset erot. Sos Lääk Aikak 2012:49:94-104.
32. Talvia S. Family-based dietary intervention in the STRIP study - influences on diet and diet-related attitudes. Annales Universitatis Turkuensis D 1058, Turku 2013.

33. Konttinen H, Sarlio-Lähteenkorva S, Silventoinen $\mathrm{K}$, ym. Socio-economic disparities in the consumption of vegetables, fruit and energy-dense foods: the role of motive priorities. Public Health Nutrition 2013;16:873-82. https://doi.org/10.1017/S1368980012003540

34. Kunttu K, Kylmälä M. Terveystottumusten pysyvyys ja muutokset viiden opiskeluvuoden aikana. Sos Lääk Aikak 2003;40:34-48.

35. Aalsma MC, Carpentier MY, Azzouz F, ym. Longitudinal effects of health-harming and healthprotective behaviors within adolescent romantic dyads. Soc Sci Med 2012;74:1444-51. https://doi.org/10.1016/j.socscimed.2012.01.014

\section{Hanna LAGström \\ FT, ravitsemustieteen dosentti \\ Turun yliopisto \\ Kansanterveystieteen yksikkö}

\section{Sanna Luoto \\ ETM \\ Turun yliopisto \\ Kliininen laitos}

JOHANNA MäKELÄ

FT

Turun yliopisto

Biotekniikan keskus

JENNI IIROLA
VTK

Turun yliopisto

Kliininen laitos

KRISTINA KUNTTU

$L T$, terveyden edistämisen dosentti

Ylioppilaiden terveydenhoitosäätiö 
LIITE 1. Ruokavalion laatua mittaava IDQ -mittari (Index of Diet Quality) ja sen pisteytysohje.

Täyttöohje: Vastaa jokaiseen kysymykseen. Valitse vain yksi vaihtoehto tai vastaus jokaiseen kysymykseen.

1. Kuinka monta viipaletta leipää syötte päivässä? viipaletta (ohje: kokonainen sämpylä $=2$ viipaletta)

2. Syömänne leipä on pääsääntöisesti

1. ruisleipää tai näkkileipää

2. täysjyväleipää

3. valkoista leipää

4. en syö leipää

3. Kuinka monena päivänä viikossa syötte täysjyväviljavalmisteita (esim. leipä, puuro, mysli)? päivänä $(0-7,0=$ harvemmin kuin kerran

viikossa, $7=$ joka päivä)

4. Käytätte leivällä tavallisesti

1. en mitään

2. rasvalevitettä, jossa korkeintaan $40 \%$ rasvaa (esim. Keiju Keveämpi 30, Keiju Kevyt 40, Flora

Kevyt 40, Kevyt Becel 35, Kevyt Levi 40)

3. rasvalevitettä, jossa $60 \%$ rasvaa (esim. Becel 60 , Keiju 60, Kultarypsi 60)

4. rasvalevitettä, jossa 70-80\% rasvaa (esim.

Flora 70, Keiju 70)

5. voi-kasviöljyseosta, rasvaseosta (esim. Oivariini, Enilett)

6. voita

7. kasvisterolimargariinia (esim. Becel pro activ, Benecol)

5. Käyttämänne salaatinkastike on yleensä

1. öljypohjainen

2. kermaviilipohjainen

3. majoneesipohjainen

4. kevyt kastike

5. en käytä salaatinkastiketta

6. Kuinka monena päivänä viikossa syötte kalaa? päivänä $(0-7,0=$ harvemmin kuin kerran viikossa, 7=joka päivä)

7. Juomanne maito tai piimä on pääsääntöisesti

1. täysmaitoa

2. kevytmaitoa tai piimää, jossa rasvaa $2,5 \%$ (esim. ab-piimä)

3. ykkösmaitoa tai piimää, jossa rasvaa $1 \%$

4. rasvatonta maitoa tai rasvatonta piimää

5. en juo maitoa tai piimää

8. Kuinka monena päivänä viikossa nautitte nestemäisiä maitovalmisteita (esim. maito, piimä, maitojuoma, jogurtti, viili)? päivänä $(0-7,0=$ harvemmin kuin kerran

viikossa, $7=$ joka päivä)

9. Kuinka monta annosta nestemäisiä

maitovalmisteita (esim. maito, piimä, maitojuoma, jogurtti, viili) syötte päivittäin? annosta $(1$ annos= $2 \mathrm{dl})$

10. Kuinka monena päivänä viikossa syötte kasviksia? päivänä $(0-7,0=$ harvemmin kuin kerran viikossa, 7=joka päivä)

11. Kuinka monta annosta kasviksia syötte päivässä? annosta $(0=$ en yhtään)

1 annos= esim. 1 tomaatti tai noin $1 \mathrm{dl}$ raastetta tai 2 porkkanaa

12. Kuinka monena päivänä viikossa syötte hedelmiä tai marjoja? päivänä $(0-7,0=$ harvemmin kuin kerran viikossa, $7=$ joka päivä)

13. Kuinka monta annosta marjoja ja hedelmiä syötte päivässä? annosta $(0=$ en yhtään)

1 annos= esim. 1 omena tai banaani tai noin $1 \mathrm{dl}$ marjoja

14. Kuinka monena päivänä viikossa juotte hedelmäja marjamehuja? päivänä $(0-7,0=$ harvemmin kuin kerran viikossa, $7=$ joka päivä)

15. Kuinka monta lasillista hedelmä- ja marjamehuja keskimäärin juotte päivässä? lasillista $(1$ lasi $=2 \mathrm{dl})$

16. Kuinka monena päivänä viikossa juotte sokeria sisältäviä virvoitusjuomia (myös energiajuomat)? päivänä $(0-7,0=$ harvemmin kuin kerran viikossa, $7=$ joka päivä)

17. Kuinka monena päivänä viikossa syötte makeisia (myös suklaata)? päivänä $(0-7,0=$ harvemmin kuin kerran viikossa, $7=$ joka päivä)

18. Kuinka monena päivänä viikossa jätätte lounaan tai päivällisen väliin kiireen tai muun syyn takia? päivänä $(0-7,0=$ harvemmin kuin kerran viikossa, 7=joka päivä) 
LIITE2. Ruokavalion laatua kuvaavan ravintomittarin kysymysten pisteytysohjeet. Kokonaispisteet vaihtelevat $0-15$ välillä ja ruokavalio voidaan luokitella terveyttä edistäväksi, kun pisteitä on 10 tai enemmän.

\begin{tabular}{|c|c|}
\hline Kysymys & Pisteytys \\
\hline & Täysjyväviljatuotteet $(0-3 \mathrm{p})$ \\
\hline 1. & Leipää 4 viipaletta tai enemmän päivässä $=1 \mathrm{p}$ \\
\hline 2. & $\begin{array}{l}\text { 2. Leivän tulisi olla pääsääntöisesti täysjyväleipää, ruis- tai näkkileipää } \\
\text { vaihtoehto } 1 \text { tai } 2=1 \mathrm{p}\end{array}$ \\
\hline \multirow[t]{2}{*}{3.} & $\begin{array}{l}\text { 3. Täysjyväviljavalmisteita (esim. puuro, leipä) päivittäin } \\
\text { vastaus } 7=1 \mathrm{p}\end{array}$ \\
\hline & Rasva $(0-4 p)$ \\
\hline 4. & $\begin{array}{l}\text { 4. Leivällä kasvirasvalevite } \\
\text { vaihtoehto } 2,3 \text { tai } 4=1 \mathrm{p}\end{array}$ \\
\hline 5. & $\begin{array}{l}\text { 5. Salaatinkastikkeena öljypohjainen kastike } \\
\text { vaihtoehto } 1=1 \mathrm{p}\end{array}$ \\
\hline 6. & $\begin{array}{l}\text { 6. Kalaa vähintään kaksi kertaa viikossa } \\
\text { vastaus } 2 \text { tai enemmän }=1 \mathrm{p}\end{array}$ \\
\hline \multirow[t]{2}{*}{7.} & $\begin{array}{l}\text { 7. Maito ja piimä rasvattomana tai vähärasvaisena } \\
\text { vaihtoehto } 3 \text { tai } 4=1 \mathrm{p}\end{array}$ \\
\hline & Maitotuotteet $(0-1 \mathrm{p})$ \\
\hline \multirow[t]{2}{*}{$8-9$} & $\begin{array}{l}\text { 8. Nestemäisiä maitovalmisteita päivittäin } \\
\text { JA } \\
\text { 9. Nestemäisiä maitovalmisteita } 2 \text { annosta tai enemmän päivässä } \\
\text { 8. vastaus } 7 \text { ja 9. vastaus } 2 \text { tai enemmän }=1 \mathrm{p}\end{array}$ \\
\hline & Kasvikset, marjat ja hedelmät $(0-3$ p) \\
\hline \multirow[t]{2}{*}{$10-13}$. & $\begin{array}{l}\text { Kasviksia, marjoja ja hedelmiä vähintään } 400 \mathrm{~g} \text { päivässä joka päivä. Annoksiksi muutettuina tämä } \\
\text { tarkoittaa noin } 2-3 \text { annosta kasviksia sekä } 2-3 \text { annosta marjoja ja hedelmiä päivittäin. } \\
\text { Kysymys } 10^{*} 11+\text { kysymys } 12 * 13=\text { annosten lukumäärä } \\
1 \text { annos }=0,16 \mathrm{p}(\max 3 \mathrm{p})\end{array}$ \\
\hline & Sokeri $(0-3 \mathrm{p})$ \\
\hline $14-15$. & $\begin{array}{l}\text { Hedelmä- ja marjamehuja korkeintaan lasillinen päivässä } \\
\text { vastaus } 14 \mathrm{x} \text { vastaus } 15=7 \text { tai vähemmän }=1 \mathrm{p}\end{array}$ \\
\hline 16. & $\begin{array}{l}\text { Virvoitusjuomia harvoin, korkeintaan kerran viikossa } \\
\text { vastaus } 1 \text { tai } 0=1 \mathrm{p}\end{array}$ \\
\hline \multirow[t]{2}{*}{17.} & $\begin{array}{l}\text { 17. Makeisia harvoin, korkeintaan kerran viikossa } \\
\text { vastaus } 1 \text { tai } 0=1 \mathrm{p}\end{array}$ \\
\hline & Ateriarytmi $(0-1 \mathrm{p})$ \\
\hline \multirow[t]{2}{*}{18.} & $\begin{array}{l}\text { 18. Ateriarytmin tulisi olla säännöllinen. } \\
\text { Vastaus } 0,1 \text { tai } 2=1 \mathrm{p}\end{array}$ \\
\hline & Pisteet yhteensä 0-15p \\
\hline
\end{tabular}

